\title{
SAVING THE PANGOLIN: PHILIPPINES' FIGHT AGAINST ILLEGAL WILDLIFE TRADE
}

by IAN KENDRICH FONTANILLA

Institute of Biology, University of the Philippines, Diliman, Philippines

Governments, scientists, and enforcement agencies join forces to formally incorporate molecular identification of trafficked species within wildlife forensics.

$\mathrm{O}$ n April 8, 2013, a Chinese-registered fishing vessel ran aground on Tubbataha Reef, a marine protected area southeast of the island province of Palawan, Philippines. When the ship was towed to port at Puerto Princesa City, it was found to contain 400 concealed boxes with more than 3,000 frozen pangolins. These specimens were initially thought to be the Palawan Pangolin (Manis culionensis), an IUCN-listed endangered species. This and many other pangolin species have been described as some of the most trafficked animals on Earth as they are priced for their 'scales' for supposed medicinal value as well as for their exotic meat, both of which fetch a high value in the Chinese market.
The Palawan Pangolin and many other Philippine endemic species are protected by the Philippine Wildlife Resources Conservation and Protection Act (Republic Act 9147), which prohibits the capture, sale and transport of threatened species. However, Philippine Wildlife Enforcement Officers (WEOs) are hindered from carrying out their duties because they are limited in their ability to correctly identify confiscated species, which is often based on morphology alone. More often, WEOs have to deal with specimens that are not intact (e.g. tissue, blood, bone, etc.), rendering a taxonomic identification impossible. This poses a significant challenge for WEOs who need to correctly identify confiscated specimens and prosecute poachers. 
Going back to the Tubbataha case, the Department of Environment and Natural Resources (DENR) sought the help of the University of the Philippines Diliman, Institute of Biology (UPD-IB) through its DNA Barcoding Laboratory to identify the pangolin specimens. Adrian Luczon, the lead investigator for the molecular identification of the specimens, utilized the COI gene and two reference Manis culionensis samples. His team's results demonstrated that the Tubbataha specimens actually belonged to another critically endangered species, the Sunda Pangolin ( $M$. javanica) native to mainland Southeast Asia, Borneo, Java, Sumatra, and nearby islands.

Despite the DNA barcoding results indicating the specimens to be from another species outside the Philippines, the trafficking of the Palawan Pangolin remains unabated. In fact, within the same year, several batches of confiscations involving these pangolins have taken place, which Luczon's team identified as the Palawan Pangolin through DNA barcoding. Clearly, there was an urgent need to formally incorporate molecular identification of trafficked species within the wildlife forensics work in the Philippines.

In 2015, UPD-IB entered a collaboration with the DENR through its Biodiversity Management Bureau to establish the first Molecular Wildlife Forensics (WILDFORCE) Lab in the Philippines. Through this partnership, DENR provides samples of Philippine endemic species to populate the Philippine DNA barcode database. These samples are to be processed at the Biodiversity Research Laboratory, headed by Dr. Perry Ong, and the DNA Barcoding Laboratory of UPD-IB.

Other specimens brought to the lab for proper identification through DNA barcoding include the Philippine Duck (Anas luzonica), the Philippine Tarsier (Tarsius syrichta), the Gray's Monitor Lizard (Varanus olivaceus), and the Philippine Sailfin Lizard (Hydrosaurus pustulatus), among others.

In 2018, with financial support from the Japan Biodiversity Fund and endorsement from the Secretariat of the Convention on Biological Diversity, and in support of the Global Taxonomy Initiative, WILDFORCE was able to train 18 individuals among researchers from higher educational institutions (HEIs) and WEOs from regional DENR offices. The training aimed to capacitate these personnel on the basic principles of DNA barcoding and eventually allow them to set up their own labs.

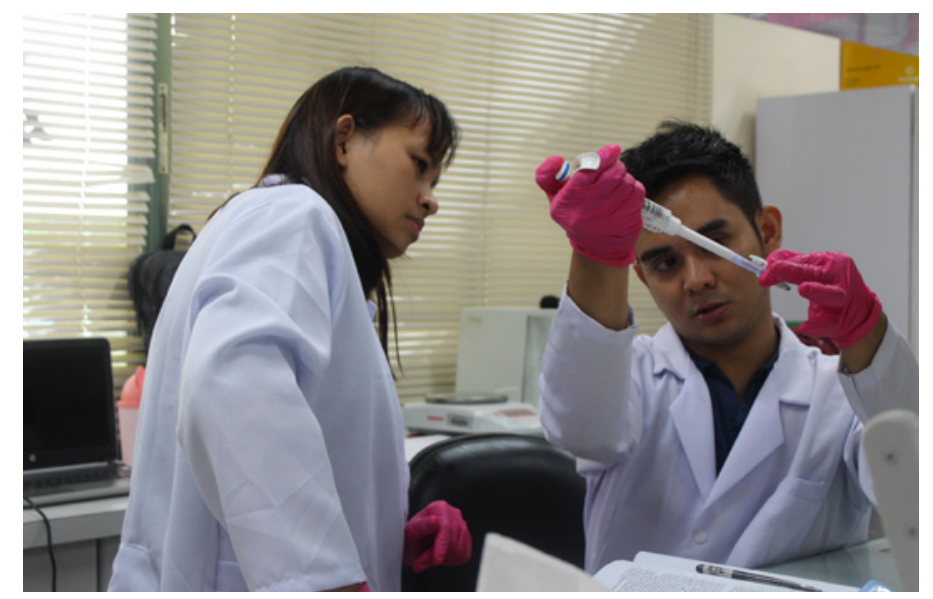

Wildlife enforcement officers and researchers from higher educational institutions receive training on DNA barcoding. PHOTO CREDIT: Adrian Luczon

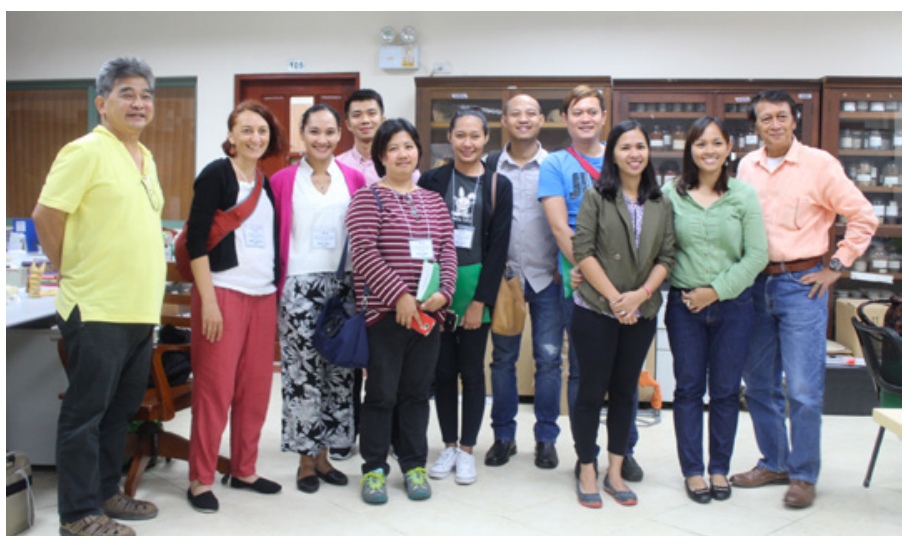

These efforts are envisioned to contribute to building a robust Philippine DNA barcode database and decentralize the processing of evidence towards the DENR regional offices and local HEIs.

The sad reality of illegal trafficking of endangered species, as manifested by the Tubbataha case, has prompted the Philippine government and various stakeholders to join forces to combat illegal wildlife trade. It is only through collective effort grounded in science that we can have a chance to protect biodiversity.

\section{Online:}

https://ibol.org/barcodebulletin/research/savingthe-pangolin-philippines-fight-against-illegalwildlife-trade/ 